\title{
STUDY OF TRIS(METHYLAMINO)BORANE AS A PRECURSOR TO BORON NITRIDE
}

\author{
B. Bonnetot, B. Frarige, F. Guilhon and H. Mongeot* \\ Laboratoire de Physicochimie minerale, Universite Claude Bernard Lyon I, \\ 43 Boulevard du 11 Novembre 1918, F-69622 Villeurbanne Cedex, France
}

\begin{abstract}
Tris(methylamino)borane, 1 , was prepared at $-80^{\circ} \mathrm{C}$ by reaction of methylamine with boron trichloride. Heating this compound up to $300^{\circ} \mathrm{C}$ resulted in its conversion to $\mathrm{B}, \mathrm{B}^{\prime}, \mathrm{B}^{\prime \prime}$ tris(methylamino)- $\mathrm{N} \mathrm{N}^{\mathrm{N}}, \mathrm{N}^{\mathrm{n}}$-trimethylborazine that condensed into a polymeric species, with methylamine evolution. The compound formed by the condensation of two borazine units was thoroughly characterised by ${ }^{11} \mathrm{~B}$ NMR and con'elated ${ }^{1} \mathrm{H}$ and ${ }^{13} \mathrm{C}$ NMR while a related compound resulting from the further condensation of borazine units could be detected. No ring opening was observed during the initial steps of the condensation reactions. Further pyrolysis of 1 above $1000^{\circ} \mathrm{C}$ resulted in the formation of boron nitride that was characterized by powder $\mathrm{X}$-ray diffraction, infrared and elemental analysis techniques. Furthermore 1 appeared to convert by heating to a mixture of suitable viscosity for BN coating applications. Thus, it appeared as a very interesting precursor to boron nitride.
\end{abstract}

\section{INTRODUCTION}

The preparation and the chemical properties of tris(alkylamino)boranes $B(N H R)_{3}$ were first reported by Lappert 1,2,3 who mentioned that their pyrolysis led to the borazine (RHNBNR) 3 and polyborazines. The infrared spectra of $\mathrm{B}\left(\mathrm{NHCH}_{3}\right)_{3}$ and $\mathrm{B}\left(\mathrm{NDCH}_{3}\right)_{3}$ have been studied ${ }^{4}$ and the ${ }^{11} \mathrm{~B}$ and ${ }^{1} \mathrm{H}$ NMR spectra of $\mathrm{B}(\mathrm{NHR})_{3}\left(\mathrm{R}=\mathrm{CH}_{3}, \mathrm{C}_{2} \mathrm{H}_{5}\right)$ and of the relevant borazine were examined supporting the aromatic character of the borazine ring 5 . The same borazines could also be prepared by reaction of the appropriate chloroborazine $(\mathrm{ClBNR})_{3}$ with primary amines. The thermal decomposition of $\mathrm{B}^{\prime}, \mathrm{B}^{\prime}, \mathrm{B}^{\prime \prime}$-tris(methylamino)- $\mathrm{N}, \mathrm{N}^{\prime}, \mathrm{N}^{n}$-trimethylborazine at temperatures below $300^{\circ} \mathrm{C}$ was studied and it was concluded that it may occur both via deamination and opening of the borazine ring ${ }^{6}$, in contrast with earlier results ${ }^{2}$. 
The structural relationship between polyborazines and boron nitride was emphasized in the early sixties $^{7}$ and in spite of the importance of boron nitride as a non-oxide ceramic the use of aminoboranes for the preparation of boron nitride via polyborazines has surprisingly not been fully explored. The fact that polyborazines were insoluble, infusible, and essentially impossible to process probably as a result of significant cross-linking chemistry even at relatively low temperatures $7,8,9,10$ has certainly limited further developments. Nevertheless aminoboranes may be used as precursors of boron nitride. Turbostratic boron nitride has been prepared by pyrolysis of tris(ethylamino)borane at $1000^{\circ} \mathrm{C}$ under an ammonia atmosphere for a MAS ${ }^{11} \mathrm{~B}$ NMR study ${ }^{11}$. BN fibers have been obtained by pyrolysis of tris(phenylamino)borane ${ }^{12}, \mathrm{~B}(\mathrm{NHPhe})_{3}$.

Our interest in aminoboranes as precursors to boron nitride was focused on the tris(methylamino) derivative because of its low carbon content. $\mathrm{B}\left(\mathrm{NHCH}_{3}\right)_{3}$ was thus prepared at a reasonable scale for the preparation of boron nitride samples. The initial steps of its thermolysis were monitored by ${ }^{1} \mathrm{H}$, ${ }^{11} \mathrm{~B}$ and ${ }^{13} \mathrm{C}$ NMR spectroscopy. Thermogravimetric analysis under argon up to $1000^{\circ} \mathrm{C}$ showed that tris(methylamino)borane was converted into boron nitride and carbon. Bulk thermolyses up to $1700^{\circ} \mathrm{C}$ were then performed under argon or more conveniently under ammonia to lower the carbon content and obtain white hexagonal boron nitride.

\section{EXPERIMENTAL SECTION}

\section{Materials and Methods}

Standard inert-atmosphere techniques were used for the syntheses and manipulations. All products were manipulated in an efficient dry box. Solvents were all dried on activated molecular sieves (Merck $5 \AA$ ) before being used. NMR spectra were obtained with a Bruker AM 300 spectrometer at $96.28 \mathrm{MHz}$ for ${ }^{11} \mathrm{~B}$ with $\mathrm{BF}_{3} \cdot \mathrm{Et}_{2} \mathrm{O}$ as an external reference (positive values downfield) and with $\mathrm{CH}_{2} \mathrm{Cl}_{2}$ as a solvent. They were obtained at $300 \mathrm{MHz}$ for ${ }^{1} \mathrm{H}$ and $75 \mathrm{MHz}$ for ${ }^{13} \mathrm{C}$. Solvents used were $\mathrm{CDCl}_{3}$ with TMS (SiMe 4 ) as an internal reference or $\mathrm{CCl}_{4}$ with $\mathrm{C}_{6} \mathrm{D}_{6}$ as an external reference. Abbrevations used in NMR are : $s=$ singlet ; $d=$ doublet ; $q=$ quartet ; $b=$ broad. The infrared spectra were obtained from $\mathrm{KBr}$ pellets on a Perkin Elmer 840 spectrometer. Thermogravimetric analyses were performed on a Setaram Model B70 instrument. Elemental analysis were obtained from the SCA of Solaize.

\section{Synthesis}

Methylamine (Fluka, $97 \%$ ) and N25 boron trichloride (Alphagaz) were used as received in steel cylinders. The highly exothermic reaction of boron trichloride with methylamine was carried out with the apparatus represented in Figure 1 . In a typical experiment the pentane solution of methylamine contained in flask $\mathrm{L}$ (225 g, $7.25 \mathrm{~mol}$, of $\mathrm{CH}_{3} \mathrm{NH}_{2}$ in $600 \mathrm{~cm}^{3}$ of pentane ) was totally introduced in the 2l three-necked reaction flask maintained at $-80^{\circ} \mathrm{C} .150 \mathrm{~cm}^{3}$ of the pentane solution of $\mathrm{BCl}_{3}$ (260 $\mathrm{g}$ (2.22 mol) of $\mathrm{BCl}_{3}$ in $120 \mathrm{~cm}^{3}$ of pentane) contained in flask $\boldsymbol{M}$, were then dropwise added in $90 \mathrm{mn}\left(\mathrm{BCl}_{3}\right.$ : $\left.92.4 \mathrm{~g}, 0.79 \mathrm{~mol}\right)$. A small amount of solid methylamine hydrochloride with two liquid 
phases were obtained, the upper phase was a pentane solution of $\mathrm{B}\left(\mathrm{NHCH}_{3}\right)_{3}$ and the lower phase contained methylamine hydrochloride dissolved in methylamine. When the reaction mixture was allowed to warm up to room temperature methylamine slowly distilled while more solid was formed. The flask-content was filtered and the residual solid washed with pentane. Pentane was then removed $\left(20^{\circ} \mathrm{C}, 1000 \mathrm{~Pa}\right)$ from the solution and $50 \mathrm{~g}$ of liquid (yield $=62.7 \%$ ) was collected. It contained tris(methylamino)borane and $\mathrm{B}, \mathrm{B}^{\prime}, \mathrm{B}^{\mathrm{n}}$-tris(methylamino)-N, $\mathrm{N}^{\prime}, \mathrm{N}^{\mathrm{n}}$-trimethylborazine in a 91 : 9 molar ratio. The aminoborane to borazine ratio slowly changed at room temperature to reach a 85:15 stable value after several days. These results were infered from the corresponding ${ }^{11} \mathrm{~B}$ NMR spectra : $\delta^{11} \mathrm{~B}\left(\mathrm{~B}\left(\mathrm{NHCH}_{3}\right)_{3}\right)=24.5 \mathrm{ppm}\left(\mathrm{Lit}: 24.6 \mathrm{ppm}^{13}, 24.2 \mathrm{ppm}{ }^{14}\right), \delta^{11} \mathrm{~B}\left(\left(\mathrm{CH}_{3} \mathrm{NBNHCH}_{3}\right)_{3}\right)=$ $27.5 \mathrm{ppm}$ (Lit : $27.0 \mathrm{ppm}^{4}$ ). The residual solid contained both the expected hydrochloride, $\mathrm{CH}_{3} \mathrm{NH}_{3} \mathrm{Cl}$, and methylammonium tetrachloroborate, $\mathrm{CH}_{3} \mathrm{NH}_{3} \mathrm{BCl}_{4},\left(\delta^{11} \mathrm{~B}=6.4 \mathrm{ppm}\right.$ in $\mathrm{CH}_{2} \mathrm{Cl}_{2}$, $\mathrm{Lit}^{15}=6.5 \mathrm{ppm}$ in $\mathrm{CH}_{2} \mathrm{Cl}_{2}$ ). Pure $\mathrm{B}(\mathrm{NHMe})_{3}$ was isolated by fractional distillation .The ${ }^{1} \mathrm{H}$ and ${ }^{13} \mathrm{C}$ NMR data summarized in tables I and II are in line with those from the literature ${ }^{5}$ which gives the following ${ }^{1} \mathrm{H}$ NMR data : $\delta \mathrm{NH}=1.50 \mathrm{ppm}(\mathrm{b})$ and $\delta \mathrm{CH}_{3}=2.52 \mathrm{ppm}\left(\mathrm{d}, \mathrm{J}=6.3 \mathrm{~Hz}\right.$ ) in $\mathrm{CDCl}_{3}$. As reported earlier 5 the expected quartet for the $\mathrm{NH}$ groups was not observed.

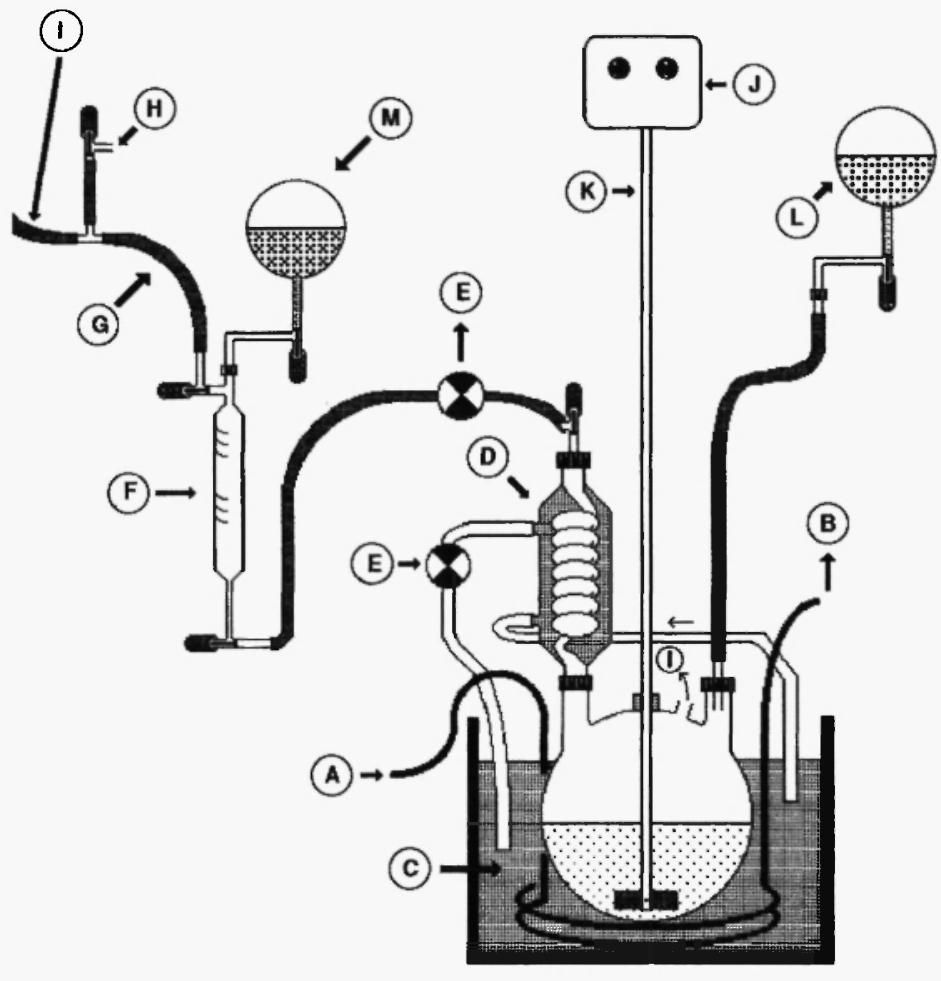

Figure 1 : Schematic view of the apparatus used for the aminoborane synthesis.

(A) Liquid nitrogen circulating through a cupper cooling coil ; (B) Nitrogen (outflow) ; (C) Methanol freezing bath ; (D) Cooling funel for dropwise addition of $\mathrm{BCl}_{3}$; (E) Pump ; $\mathrm{F}$ ) Graduated ampoule ; (G) Teflon pipe ; (H) Venting ; (I) Connexion to the vacuum line ; (J) Motor ; (K) Stirrer ; (L) Pentane solution of methylamine ; (M) Pentane solution of $\mathrm{BCl}_{3}$. 
Pyrolyses up to $250^{\circ} \mathrm{C}$

Pure tris(methymamino)borane $(10 \mathrm{~g})$ was very slowly heated up to $250^{\circ} \mathrm{C}$ while the pressure was maintained at $100 \mathrm{mmHg}$ in order to eliminate the methylamine evolved. Different samples were obtained by heating the liquid for 12 hours at $120^{\circ} \mathrm{C}$ (sample a), 48 hours at $120^{\circ} \mathrm{C}$ (sample b), then 12 hours at $180^{\circ} \mathrm{C}$ (sample $\mathrm{C}$ ) and then $20 \mathrm{~h}$ at $250^{\circ} \mathrm{C}$ (sample d). The mixtures collected, more and more viscous but all soluble in $\mathrm{CCl}_{4}$, were studied by ${ }^{11} \mathrm{~B},{ }^{1} \mathrm{H}$ and ${ }^{13} \mathrm{C}$ NMR spectroscopy. Unless otherwise stated, all ${ }^{1} \mathrm{H}$ and ${ }^{13} \mathrm{C}$ NMR spectra were recorded with $\mathrm{CCl}_{4}$ as a solvent rather than $\mathrm{CDCl}_{3}$ which precluded the observation of some spin-spin couplings because of an exchange. The ${ }^{1} \mathrm{H}$ NMR spectra obtained are shown in Figure 2. The second sample (b) contained mainly the borazine derivative (MeNBNHMe)3. Despite repeated distillations, this compound was never obtained in totally pure form. Indeed the ${ }^{1} \mathrm{H}$ NMR spectrum always displayed additionnal weak resonances pertaining to oligomeric species. The ${ }^{1} \mathrm{H}$ NMR data, concerning the borazine, in accordance with those from the literature ${ }^{5}$ ( $\mathrm{Lt}: \delta \mathrm{N}^{-\mathrm{CH}_{3}}=2.76, \delta \mathrm{B}-\mathrm{NHCH}_{\underline{3}}=2.86(\mathrm{~d}, \mathrm{~J}=6.2 \mathrm{~Hz}$ ) and $\delta \mathrm{B}-\mathrm{NHCH}_{3}=1.90 \mathrm{ppm}(\mathrm{q})$ with $\mathrm{CCl}_{4}$ as solvent) are summarized besides ${ }^{13} \mathrm{C} \mathrm{NMR}$ data in tables I and II. The last two samples contained polymeric species.

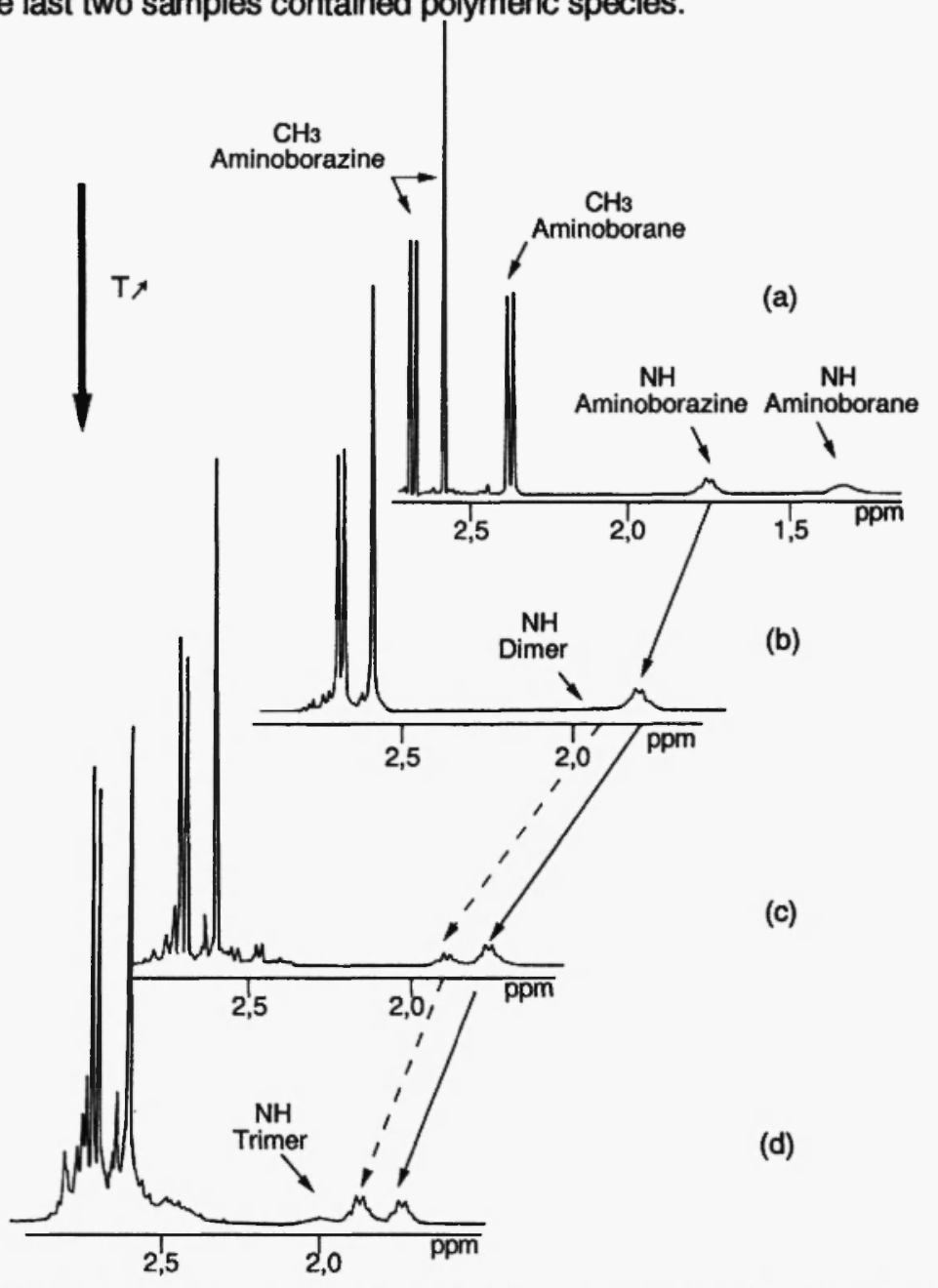

Figure 2 $2:{ }^{1} \mathrm{H}$ NMR spectra of the tris(methylarnino)borane after heating 2 hours at $120^{\circ} \mathrm{C}(\mathrm{a})$, 48 hours at $120^{\circ} \mathrm{C}$ (b), 12 hours at $180^{\circ} \mathrm{C}$ (c), $20 \mathrm{~h}$ at $250^{\circ} \mathrm{C}$ (d). 
Table I: ${ }^{1} \mathrm{H}$ NMR chemical shifts for 1.2 and 3.

\begin{tabular}{|c|c|c|c|c|c|c|}
\hline \multirow{3}{*}{ Compound } & \multirow{3}{*}{ Solvent } & \multicolumn{5}{|c|}{$\delta^{1} \mathrm{H}$ (ppm) } \\
\hline & & \multicolumn{2}{|c|}{ Amino group } & \multicolumn{2}{|c|}{ Borazine ring } & Bridge \\
\hline & & $\mathrm{CH}_{3}$ & NH & \multicolumn{2}{|c|}{$\mathrm{CH}_{3}$} & $\mathrm{CH}_{3}$ \\
\hline \multirow{4}{*}{$\begin{array}{c}1 \\
\mathrm{~B}(\mathrm{NHMe})_{3}\end{array}$} & $\mathrm{CDCl}_{3}$ & 2.52 (d) & 1.66 (b) & \multicolumn{2}{|c|}{ - } & - \\
\hline & & $3 \mathrm{~J}=6.0 \mathrm{~Hz}$ & & \multirow{3}{*}{\multicolumn{2}{|c|}{ - }} & \\
\hline & $\mathrm{CCl}_{4}$ & $2.36(d)^{\star}$ & $1.33(b, q)$ & & & - \\
\hline & & ${ }^{3} \mathrm{~J}=6.2 \mathrm{~Hz}$ & & & & \\
\hline 2 & $\mathrm{CDCl}_{3}$ & $2.77(\mathrm{~s})$ & 1.99 (b) & \multirow{3}{*}{\multicolumn{2}{|c|}{$\begin{array}{l}2.71(\mathrm{~s}) \\
2.59(\mathrm{~s})\end{array}$}} & - \\
\hline$(\mathrm{NHMeBNMe})_{3}$ & $\mathrm{CCl}_{4}$ & 2.69 (d) & $1.75(b, q)$ & & & - \\
\hline & & $3 \mathrm{~J}=6.2 \mathrm{~Hz}$ & & & & \\
\hline \multirow{2}{*}{$\begin{array}{c}3^{\star \star} \\
\text { (Diborazine) }\end{array}$} & $\mathrm{CCl}_{4}$ & 2.72 (d) & $1.89(b, q)$ & $2.59(\mathrm{~s})$ & $2.63(\mathrm{~s})$ & $2.64(\mathrm{~s})$ \\
\hline & & $3 \mathrm{~J}=6.2 \mathrm{~Hz}$ & & & & \\
\hline
\end{tabular}

* $A$ very weak doublet centered at $2.36 \mathrm{ppm}$ due to the spin-spin coupling between ${ }^{1} \mathrm{H}$ and ${ }^{13} \mathrm{C}$ nuclei $\left({ }^{1} \mathrm{~J}_{\mathrm{C}-\mathrm{H}}=\right.$ $134.3 \mathrm{~Hz}$ ) was observed.

${ }^{* *}$ Resonances at $\delta 2.59,2.63$ and 2,64 ppm appeared in a 4:2:1 ratio. The three corresponding singlets were assigned from the $2 \mathrm{D}{ }^{1} \mathrm{H}-{ }^{13} \mathrm{C}$ data.

Table II: ${ }^{13} \mathrm{C}$ NMR chemical shifts for 1, 2 ard 3.

\begin{tabular}{|c|c|c|c|c|c|}
\hline \multirow{3}{*}{ Compound } & \multirow{3}{*}{ Solvent } & \multicolumn{4}{|c|}{$\delta^{13} \mathrm{C}(\mathrm{ppm})$} \\
\hline & & Amino group & \multicolumn{2}{|c|}{ Borazine ring } & Bridge \\
\hline & & $\mathrm{C}_{3}$ & \multicolumn{2}{|c|}{$\mathrm{C}_{\mathrm{H}_{3}}$} & $\mathrm{CH}_{3}$ \\
\hline $\begin{array}{c}1 \\
\mathrm{~B}(\mathrm{NHMe})_{3}\end{array}$ & $\begin{array}{l}\mathrm{CDCi}_{3} \\
\mathrm{CCl}_{4} \\
\end{array}$ & $\begin{array}{c}27.3 \\
{ }^{1} \mathrm{~J}_{\mathrm{CH}}=132.9 \mathrm{~Hz} \\
\mathrm{~h}_{1 / 2}=3.1 \mathrm{~Hz} \\
27.8\end{array}$ & \multicolumn{2}{|c|}{-} & - \\
\hline $\begin{array}{l}2^{\star} \\
(\mathrm{NHMeBNMe})_{3}\end{array}$ & $\begin{array}{l}\mathrm{CDCi}_{3} \\
\mathrm{CCl}_{4} \\
\end{array}$ & $\begin{array}{c}30.1 \\
1 \mathrm{~J}_{\mathrm{CH}}=134.1 \mathrm{~Hz} \\
\mathrm{~h}_{1 / 2}=2 \mathrm{~Hz} \\
30.9\end{array}$ & \multicolumn{2}{|c|}{$\begin{array}{c}31.9 \\
{ }^{1} \mathrm{~J}_{\mathrm{CH}}=133.5 \mathrm{~Hz} \\
\mathrm{~h}_{1 / 2}=1 \mathrm{~Hz} \\
32.6\end{array}$} & - \\
\hline $\begin{array}{c}3^{\star \star} \\
\text { (Diborazine) }\end{array}$ & $\mathrm{CCl}_{4}$ & 30.3 & 31.9 & 33.2 & 33.8 \\
\hline
\end{tabular}

* The spectrum obtained by ${ }^{13} \mathrm{C}$ NMR (coupled with ${ }^{1} \mathrm{H}$ ) gave two accidentally overlapped quartets. $h_{1 / 2}$ were mesured on the two extreme unoverlapped peaks. The largest, centered at $30.1 \mathrm{ppm}$, was assigned to the $\mathrm{NHCH}_{3}$. The broadening was supposed to result from the ${ }^{2} \mathrm{~J}_{\mathrm{HNH}}$ spin-spin coupling. This assignment was corroborated by $2 \mathrm{D}^{1} \mathrm{H}-{ }^{1} \mathrm{H}$ and ${ }^{1} \mathrm{H}^{-13} \mathrm{C}$ COSY.

** The assignment was deduced from the pics intensities in the ${ }^{13} \mathrm{C}$ spectrum (respectively 4-4-2-1) supposing that the relaxation times for the different $\mathrm{CH}_{3}$ had comparable values and was corroborated by the $2 \mathrm{D}{ }^{1} \mathrm{H}-{ }^{13} \mathrm{C}$ analysis. 
Thermogravimetric analyses

The crude stable mixture (Molar ratio : $85 \%$ of aminoborane and $15 \%$ of the corresponding borazine) was first studied as a precursor for boron nitride by thermogravimetric analysis (TGA). Thermograms (Figure 3) were made on $150 \mathrm{mg}$ samples under $\mathrm{Ar}$ and under $\mathrm{NH}_{3}$. TGA under $\mathrm{Ar}$ led to a black residue with a ceramic yield of $25 \%$ and TGA under $\mathrm{NH}_{3}$ to a white solid with a ceramic yield of $15 \%$. Infrared spectra of the solids showed two absorptions typical of boron nitride 16 centered at $1430 \mathrm{~cm}^{-1}$ (strong broad band) and $\approx 800 \mathrm{~cm}^{-1}$ (medium sharp band). Weak bands were also in both cases observed at $3440 \mathrm{~cm}^{-1}$ ( N-H groups), at $3200 \mathrm{~cm}^{-1}$ (B-O-H) groups and three sharp bands at 2960,2940, $2860 \mathrm{~cm}^{-1}\left(-\mathrm{CH}_{3}\right.$ stretching modes). Furthermore, no characteristic sharp reflections of hexagonal boron nitride were observed in either XRD profile but in both cases spectra displayed two broad diffractions centered at $2 \theta=24.9^{\circ}$ and $2 \theta=42.5^{\circ}$ showing the presence of boron nitride with low cristallinity 17 . The former was ascribed to the [002] diffraction of hexagonal boron nitride, the latter to the [100] and [101] diffractions of h-BN.

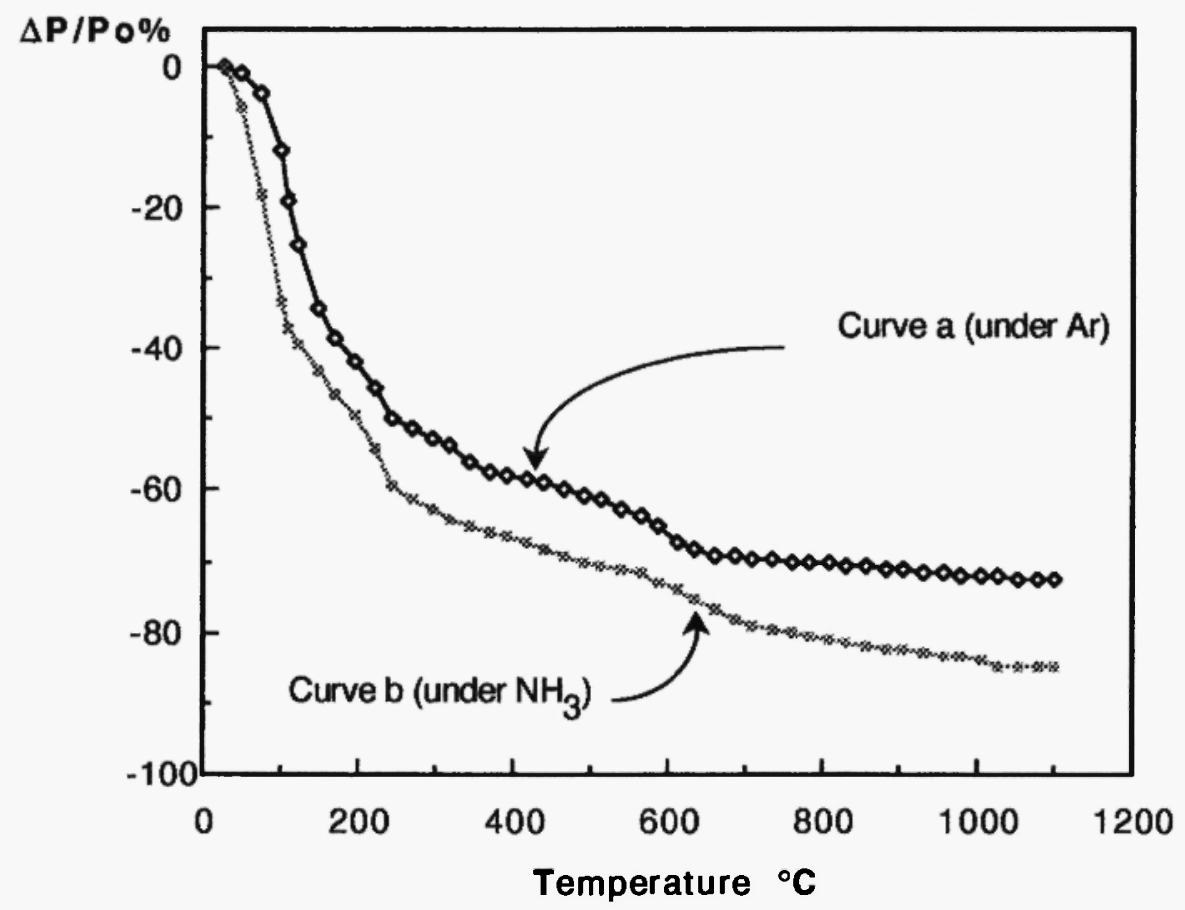

Figure $3:$ Thermogravimetric analyses of the precursor (Rate $=2^{\circ} \mathrm{C} / \mathrm{mn}$ ). Curve a : under a stream of $\operatorname{Ar}(1 / / h)$. Curve $b$ : under a stream of $\mathrm{NH}_{3}(1 / / h)$.

Bulk pyrolyses up to $\mathrm{T}>1000^{\circ} \mathrm{C}$

A sample (5 g) of the precursor (Molar ratio : $85 \%$ of aminoborane and 15\% of borazine) was heated in a tube furnace under a flow of $\mathrm{N}_{2}(10 \mathrm{ml} / \mathrm{mn})$ at a heating rate of $3^{\circ} \mathrm{C} / \mathrm{mn}$ up to $\approx 1100{ }^{\circ} \mathrm{C}$ and then was maintained for 2 hours at this temperature. The black solid (1.2 g) obtained displayed 
similar infrared spectrum and $X$-ray powder pattern to the residue obtained by TGA under Ar. It contained significant amounts of carbon according to its elemental analysis. Anal. Calcd. for BN : B, 43.6; $N, 56.4$. Anal. Found : $B, 33.4 ; C, 15.4 ; N, 45.4 ; H ; 0.6 ; O, 5.3$.

A sample $(5 \mathrm{~g})$ of the precursor was pyrolyzed under a flow of ammonia (10 $\mathrm{ml} / \mathrm{mn}$ ) up to $1000^{\circ} \mathrm{C}$ (heating rate $=3^{\circ} \mathrm{C} / \mathrm{mn}$ ) and then was maintained for two hours at this temperature. A white powder $(0.8 \mathrm{~g})$ was collected having identical infrared spectrum and powder X-Ray diffraction pattern to the residue obtained by TGA. Anal. Calcd. for BN : B, 43.6; N, 56.4. Anal. Found : B, 40,$3 ; \mathrm{C}, 0.4 ; \mathrm{N}, 58.0 ; \mathrm{H} ; 0.8 ; \mathrm{O}, 4.0$. Another solid was obtained by heating $200 \mathrm{mg}$ of the residue by classical high frequency heating at $10^{-4}$ mbar pression for $1 \mathrm{~h}$ at $1400^{\circ} \mathrm{C}$. A last sample was then prepared, according to the same procedure, by heating the residue $(200 \mathrm{mg})$ for $1 \mathrm{~h}$ at $1700^{\circ} \mathrm{C}$. The XRD measurements indicated that gradual organization of the lattice occured as evidence by the sharpening of the [002] peak toward the $3.33 \dot{A}$ value showing the formation of hexagonal boron nitride ${ }^{18}$. Furthemore, a noticeable decrease in intensity of the absorptions assigned to $\mathrm{NH}$ $\left(3440 \mathrm{~cm}^{-1}\right), \mathrm{BOH}\left(3200 \mathrm{~cm}^{-1}\right)$ and $\mathrm{CH}_{3}\left(2860,2940,2960 \mathrm{~cm}^{-1}\right)$ groups was observed by infrared spectroscopy. This last spectrum was typical of hexagonal boron nitride.

\section{RESULTS AND DISCUSSIONS}

The reaction of boron trichloride with methylamine (eq 1) has been studied by Niedenzu and coworkers 4 :

$$
6 \mathrm{CH}_{3} \mathrm{NH}_{2}+\mathrm{BCl}_{3} \rightarrow \mathrm{B}\left(\mathrm{NHCH}_{3}\right)_{3}+3 \mathrm{CH}_{3} \mathrm{NH}_{3} \mathrm{Cl}
$$

The presence of $\left(\mathrm{CH}_{3} \mathrm{NBNHCH}_{3}\right)_{3}$ besides $\mathrm{B}\left(\mathrm{NHCH}_{3}\right)_{3}$ may be due to the reaction of the intermediate species $\mathrm{ClB}\left(\mathrm{NHCH}_{3}\right)_{2}$ with methylamine explaining that excess $\mathrm{CH}_{3} \mathrm{NH}_{2}$ favours the formation of the borazine derivative. The aminoborane to borazine ratio that we obtained is consistent with those published. The mechanism proposed also involves complexes such as $\mathrm{CIB}\left(\mathrm{NHCH}_{3}\right)_{2}-\left(\mathrm{NH}_{2} \mathrm{CH}_{3}\right)$ allowing the stabilisation of $\mathrm{ClB}\left(\mathrm{NHCH}_{3}\right)_{2}$. We believe that the boron trichloride complex $\mathrm{BCl}_{3}-\mathrm{NH}_{2} \mathrm{CH}_{3}$ is also involved and that the formation of methylammonium tetrachloroborate characterized in the residual solid was due to the reaction in the lower liquid phase shown in eq 2 . This side reaction explains that quantitative yields were not obtained.

$$
\mathrm{BCl}_{3}-\mathrm{NH}_{2} \mathrm{CH}_{3}+\mathrm{CH}_{3} \mathrm{NH}_{3}{ }^{+} \mathrm{Cl}^{-} \rightarrow \mathrm{CH}_{3} \mathrm{NH}_{3}{ }^{+} \mathrm{BCl}_{4}^{-}+\mathrm{CH}_{3} \mathrm{NH}_{2}
$$

$\mathrm{B}\left(\mathrm{NHCH}_{3}\right)_{3}$ appeared to be a mobile and colourless liquid which gradually increased in viscosity and decreased in solubility by heating. At $250^{\circ} \mathrm{C}$, the mixture was a very heavy syrup which by cooling turned into a light brown, non thermoplastic brittle resin, totally unsoluble in inert organic solvents. The solubility of the mixture even after heating at $250^{\circ} \mathrm{C}$ allowed to monitor, by ${ }^{11} \mathrm{~B},{ }^{1} \mathrm{H}$ and ${ }^{13} \mathrm{C}$ NMR spectroscopy, its evolution by heating at increasing temperatures below $250^{\circ} \mathrm{C}$.

As shown in eq 3, tris(methylamino)borane, 1, converted by heating first into the related borazine derivative, 2 , then into the condensation dimer, 3 , which ultimately afforded polymeric 
species, 4 . Compounds 2 and 3 were thoroughly characterised by ${ }^{11} \mathrm{~B},{ }^{1} \mathrm{H}$ and ${ }^{13} \mathrm{C}$ NMR spectroscopy while a further condensed species was detected.<smiles>CNB1N(C)B(NC)N(C)B(NC)N1C</smiles><smiles>CNB1N(C)B(NC)N(C)B(N(C)C)N1C</smiles>

3<smiles>CB1N(C)B(N(C)C)N(C)B(C(C)(C)C)N1C</smiles>

4

The ${ }^{11} \mathrm{~B}$ NMR spectra of the samples obtained after heating (samples $b, c$ and d) displayed only one resonance centered at $27.5 \mathrm{ppm}$ which was assigned to all boron atoms of the borazine, the dimer and other polymeric species. It appeared that inequivalent boron environments were not resolved. ${ }^{1} \mathrm{H}$ NMR spectrocopy allowed to easily distinguish the different species formed in the early stages of the oligomerization. The presence of each compound 1, 2, 3 was clearly shown by a broad quartet in the high field region, attributed to the $\mathrm{N}-\mathrm{H}$ units. The chemical shifts corresponding to these $\mathrm{N}-\mathrm{H}$ units increased in the order aminoborane (1.33) < borazine (1.75) < dimer (1.89). All attempts to obtain the dimer $\left(\mathrm{B}_{3} \mathrm{Me}_{3} \mathrm{~N}_{3}(\mathrm{NHMe})_{2}\right)_{2} \mathrm{NMe}, 3$, in a pure form either by heating various samples or by distilling them under vacuum failed. The last spectrum (sample d, Figure 2 ) showed the presence of a new weak quartet $(2,01 \mathrm{ppm})$ which was assigned to $\mathrm{N}-\mathrm{H}$ units of an oligomer (possibly obtained from three borazine units). Concerning the different borazinic species, if the different $\mathrm{N}-\mathrm{H}$ protons were well resolved it was not the case for the different methyl protons giving overlapped peaks. Both the two-dimensional ${ }^{1} \mathrm{H}-{ }^{1} \mathrm{H}$ and ${ }^{1} \mathrm{H}-{ }^{13} \mathrm{C}$ correlated spectroscopy techniques (COSY) allowed the chemical shifts of all $\mathrm{CH}_{3}$ nuclei $\left({ }^{1} \mathrm{H}\right.$ and ${ }^{13} \mathrm{C}$ ) to be measured (see tables $\mathrm{I}$ and i1). A correlation signal, characteristic of the fine structure of $a^{1} \mathrm{H}$ quartet, was observed in the $2 \mathrm{D}{ }^{1} \mathrm{H}$ ${ }^{1} \mathrm{H}$ spectrum for the $\mathrm{NH}$ protons of each compound including the oligomeric species $(n=3$ ?).

Very few species resembling, 3 , in which two borazine rings are linked at boron atom sites with a NR group have been reported : model compounds ( $\left.\mathrm{Me}_{3} \mathrm{~N}_{3} \mathrm{~B}_{3} \mathrm{Me}_{2}\right)_{2} X$ have been prepared by Paine and coworkers 19 and the relevant bisborazinylamines $(X=N H, N M e)$ as well as the bisborazinylsulfide $(X=S)$ and oxyde $(X=O)$ were studied. All these four compounds were 
characterized by their ${ }^{11} \mathrm{~B}$ and ${ }^{1} \mathrm{H}$ NMR spectra and their molecular structures. It appeared that the bridging nitrogen ( $X=\mathrm{NH}, \mathrm{NMe}$ ) has a trigonal planar geometry and that the borazine rings are twisted with respect to each other : $\alpha=58^{\circ}(X=\mathrm{NH})$ and $\alpha=87.5^{\circ}(X=\mathrm{NMe})$. Furthermore, ${ }^{1} \mathrm{H}$ NMR data concerning $\left(\mathrm{Me}_{3} \mathrm{~N}_{3} \mathrm{~B}_{3} \mathrm{Me}_{2}\right)_{2} \mathrm{NMe}$, in $\mathrm{CDCl}_{3}$ as a solvent, indicated resonances at $2.90 \mathrm{ppm}$ (borazine ring $\mathrm{N}-\mathrm{Me}$ ) 2.85 ppm (borazine ring $\mathrm{N}-\mathrm{Me}$ ), 2.78 ppm (bridge $\mathrm{N}-\mathrm{Me}$ ) and $0.51 \mathrm{ppm}$ (borazine ring $\mathrm{B}-\mathrm{Me}$ ) in area ratios 2:4:1:4. In accordance with our results, very weak differences are observed between the three $\mathrm{N}$-Me chemical shifts. Furthermore these values are close to those found in the present work suggesting that here too the borazine rings are not coplanar. Another argument supporting a twisted structure is that the borazine rings are too sterically encumbered to allow a planar arrangement.

Tris(alkylamino)boranes $\mathrm{B}(\mathrm{NHR})_{3}$ are easily converted to borazine (RHNNBR) 3 and in this respect the formation of the borazine, 2 , from the aminoborane, 1 , follows a well established scheme. Condensation of borazine may occur via ring opening 6,20 or deamination as in reaction 3 . A ring opening mechanism was first described by Toeniskoetter and Hall 6 for the pyrolysis of B,B',B"-triamino-N,N',N"-triphenylborazine, $\left(\mathrm{H}_{2} \mathrm{NBNPhe}_{3}\right.$. The loss of an aniline molecule was made possible by the transfer of two hydrogen atoms or protons from the amino nitrogens to an adjacent ring nitrogen. The thermolysis of $B, B^{\prime}, B^{\prime \prime}$-triamino- $N, N^{\prime}, N^{\prime \prime}-$ trimethylborazine $\left(\mathrm{H}_{2} \mathrm{NBNCH}_{3}\right)_{3}$ proceeded both by simple polymerization and ring opening as shown by evolution of ammonia and methylamine. It was also concluded that decomposition of $\mathrm{B}^{\prime}, \mathrm{B}^{\prime}, \mathrm{B}^{\prime \prime}$-tris(methylamino)-N,N',N"trimethylborazine also may be expected to take both paths. For the same borazine decomposition, Lappert 1,2 proposed a simple polymerization path based on the observation that only methylamine evolved during heating and on an infrared study of the polymer obtained by decomposition of the related $B^{\prime}, B^{\prime}, B^{\prime \prime}$-tris(ethylamino)- $N, N^{\prime}, N^{\prime \prime}$-triethylborazine. Methylamine elimination must occur whatever the type of polymerization and so cannot indicate whether the borazine rings were affected. In this respect the spectroscopic considerations were more significant since the infrared spectrum of the polymer displayed a strong absorption at $1470 \mathrm{~cm}^{-1}$ showing that most of the borazine rings remained unaffected. Our NMR study confirms that in the initial steps, the condensation proceeds only by association of borazine rings with elimination of amine. The way aminoborazine ring condensation occurs depends on the nature of the substituents. According to Toeniskoetter and Hall the ring opening mechanism can take place if the boron substituent is a NHR moiety, but after having compared the thermal behaviour of various borazine derivatives, Paciorek et a 21 concluded that a combined total of six protons on the ring and exocyclic nitrogens is required. Thus the too limited number of protons afforded by $\mathrm{NHCH}_{3}$ substituents is consistent with the absence of ring opening in the low temperature degradation of $B, B^{\prime}, B^{\prime \prime}$-tris(methylamino) $-N, N^{\prime}, N^{\prime \prime}-$ trimethylborazine.

In order to guide the examinations of the pyrolysis chemistry of bulk samples of $B, B^{\prime}, B^{\prime \prime}-$ tris(methylamino)- $\mathrm{N}, \mathrm{N}^{\prime}, \mathrm{N}^{\prime \prime}$-trimethylborazine thermogravimetric analyses were carried out under $\mathrm{NH}_{3}$ and $\operatorname{Ar}$ (Figure 3). The first steep weight loss observed below $220^{\circ} \mathrm{C}$ is due (i) to the removal of aminoborane $\left(\mathrm{T}_{\mathrm{eb}}=59^{\circ} \mathrm{C}\right.$ at $\left.33 \mathrm{mmHg}^{1}\right)$ responsible for a decrease in the ceramic yield and (ii) to evolution of methylamine induced by cyclisation of $\mathrm{B}\left(\mathrm{NHCH}_{3}\right)_{3}$ in borazine and by the early stage of the oligomerisation chemistry. The more gradual weight loss observed between $220^{\circ} \mathrm{C}$ and $600^{\circ} \mathrm{C}$ corresponds to further three-dimensional cross-linking of borazine rings. The off-gases from 
pyrolysis of bulk samples up to $\approx 300^{\circ} \mathrm{C}$ were identified by infrared spectroscopy as methylamine only. The weight loss is more important under ammonia than under argon because as observed with B-trianilinoborazine 21 , ammonia facilitates the elimination process of amine and furthermore reacts with the precursor with amine release. Negligible under Ar the weight loss observed, above $600^{\circ} \mathrm{C}$, under the reducing ammonia atmosphere is supposed to be due to the evolution of $\mathrm{CH}_{4}$ formed after cleavage of $\mathrm{N}-\mathrm{C}$ bonds, explaining the low content of carbon obtained and the white-coloured residue. Methane has been reported 22 to form at temperatures above $500^{\circ} \mathrm{C}$ by heating precursors containing $\mathrm{CH}_{3}$ groups under $\mathrm{NH}_{3}$. As shown by infrared spectrocopy, $X$-ray diffraction and elemental analysis the solid obtained at $1000^{\circ} \mathrm{C}$ was $\mathrm{BN}$ containing $\mathrm{NH}$ and $\mathrm{NCH}_{3}$ residual groups. The carbon content could be lowered to less than $0.5 \%$ under ammonia but BN obtained at $1000^{\circ} \mathrm{C}$ was still reactive with air oxygen. After reheating to $1400^{\circ} \mathrm{C}$ or $1700^{\circ} \mathrm{C}$, the bulk samples became chemically inert tending to transform from turbostratic to hexagonal BN.

Among the features that make a precursor suitable for conversion to boron nitride by pyrolysis 16 it is generally important that the compound be liquid, fusible or soluble in an organic solvent and the pyrolysis chemistry should proceed in high yield, smoothly, without violent gas evolution. Tris(methylamino)borane or mixtures obtained after its gradual conversion to borazinic species fulfill these conditions except that due to methylamine evolution the theoretical ceramic yield is lower than $25 \%$. In the present case it is uncertain that the important weight loss affects the properties of boron nitride because amine evolution occurs in the first phase of the themolysis. The boron precursor family that has attracted the greatest attention in the preparation of boron nitride by pyrolysis is borazine and its derivatives (trichloroborazine, etc.). The use of tris(methylamino)borane instead of these compounds could be advantageous because its synthesis is easier to carry out, it undergoes polymerisation by heating without incorporation of any reactant and finally yields boron nitride simply by heating. Thus trismethylaminoborane promises to be an interesting precursor of boron nitride and we have experiments planned to investigate some possible applications.

\section{REFERENCES}

1 Aubrey, D. W. ; Lappert, M. F., J. Chem. Soc., 2927 (1959).

2 Lappert, M. F., Proc. Chem. Soc. , 59 (1959).

3 Lappert, M. F. and Majunder, M. K., Proc. Chem. Soc., 425 (1961).

4 Niedenzu, K. ; Blick, K. E. ; Boenig, I. A., Z. Anorg. Allg. Chem., 38 7, 107 (1972).

5 Pasdeloup, M. ; Cros, G. ; Commenges, G. ; Laurent, J. P., Bull. Soc. Chim. France, No 3, 754 (1971).

6 Toeniskoetter, R. H. ; Hall, F. R., Inorg. Chem., 2, No 1, 29 (1963).

7 Lappert, M. F., Developments in Inorganic Polymer Chemistry; Lappert, M. F. \& Leigh eds G. J. ; Elsevier, 20 (1962).

8 Steinberg, H.; Brotherton, R. J., Organoboron Chemistry ; New York, 2, 190 (1966).

9 Maringgele, W., The Chemistry of Inorganic Homo- and Heterocycle ; Haiduc, U., Ed. ; Academic Press : London, 1, 17 (1987). 
10 Narula, C. K. ; Schaeffer ; R. ; Datye, A. K. ; Borek, T. T. , Rapko, B. M., Paine, R., Chem. Mater. , 2, No 4, 384 (1990)

11 Marchetti, P. S. ; Known, D. ; Schmidt, W. R.; Interrante, L. V. and Maciel, G. E., Chem. Mater., 3, 482 (1991).

12 Y. Kimura, Shin Nisso Kako Co., Ltd., JP 87-26388, 1983 ; Chem. Abstr. 109(26), 235817 e.

13 Becker, W. ; Beck, W. ; Nőth, H. ; Wrackmeyer, B., Chem. Ber., 10 5, 2883 (1972).

14 Nőth, H. ; Vahrenkamp, H., Chem. Ber., 9 9, 1049 (1966).

15 Hartman, J. S. ; Schrobilgen, G. J., Inorg. Chem., 1 1, No. 5, 940 (1972).

16 Paine, R. T. ; Narula, C. K., Chem. Rev., 9 0, 73 (1990).

17 Thomas, J., Jr ; Weston, N. E. ; O'Connor, T. E., J. Am. Chem. Soc., 8 4, No. 24, 4619 (1963)

18 Pease, R. S., Acta. Cryst. 5 , 356 (1952).

19 Narula, C. K. ; Lindquist, D. A. ; Fan, M. M. ; Borek, T. T. ; Duesler, E. N. ; Datye, A. K. ;

Schaeffer, R. ; Paine, R. T., Chem. Mater., 2, No. 4, 377 (1990).

20 Paciorek, K. J. L. ; Harris, D. A. ; Kratzer, R. H., J. Polym. Sci., Polym. Chem. Ed., 2 4, 173 (1986).

21 Paciorek, K. J. L. ; Krone-Schmidt, W. ; Harris, D. H. ; Kratzer, R. H.; Wynne, K. J., ACS Symp. Ser., No. 360, 392 (1988).

22 Penot, C. ; Fabre, A. ; Goursat, P.; Bahloul, D.; Lecomte, A. ; Dauger, A. ; Lespade P., Ann. Chim. Fr., 17 , No 2, 155 (1992).

Received: January 28, 1994 - Accepted: February 24, 1994 Received in camera-ready form: March 31, 1994 
